\title{
Pityriasis Rosea: A Comprehensive Classification
}

\author{
Francesco Drago $^{a}$ Giulia Ciccarese $^{a}$ Alfredo Rebora ${ }^{a}$ Francesco Broccolo $^{b}$ \\ Aurora Parodi ${ }^{a}$ \\ aDISSAL, Department of Dermatology, IRCCS AOU San Martino-IST, University of Genoa, Genoa, and \\ ${ }^{b}$ Department of Health Sciences, University of Milano-Bicocca, Monza, Italy
}

\section{Key Words}

Pityriasis rosea $\cdot$ Human herpesvirus-6/7 · Classification

\begin{abstract}
Pityriasis rosea (PR) is an acute, self-limiting exanthematous disease associated with the endogenous systemic reactivation of human herpesvirus (HHV)-6 and/or HHV-7. The disease typically begins with a single, erythematous plaque followed by a secondary eruption with lesions on the cleavage lines of the trunk (configuration of a 'Christmas tree'). The duration may vary from 2 weeks to a few months. Besides the typical presentation of PR, atypical forms have been described. The previous classifications of PR are mainly based on its atypical morphological features rather than on the pathogenetic mechanisms that underlie the different presentations of the disease. Notably, most of the morphologically atypical forms follow a course amenable to the classic form. The classification that we propose, taking into account the pathogenesis, clinical features, and course of the disease, is easy and intuitive and may be helpful in identifying the atypical forms of PR in order to avoid misdiagnosis and establish the best treatment options. Finally, this classification provides indications for managing potentially harmful forms of PR (such as PR in pregnancy) and PR-like eruptions.
\end{abstract}

(c) 2016 S. Karger AG, Basel

\section{KARGER}

(c) 2016 S. Karger AG, Basel

$1018-8665 / 16 / 2324-0431 \$ 39.50 / 0$

E-Mail karger@karger.com

www.karger.com/drm

\section{Introduction}

Pityriasis rosea (PR) is an acute, self-limiting exanthematous disease associated with the endogenous systemic reactivation of human herpesvirus (HHV)-6 and/ or HHV-7 [1-4]. The disease typically begins with a single, erythematous scaly plaque (herald patch, HP, or mother spot) followed by a secondary eruption consisting of smaller scaly papulosquamous lesions on the cleavage lines of the trunk, giving the back the configuration of a 'Christmas tree'; it appears in crops at intervals of a few days and reaches its maximum in about 2 weeks. The duration may vary from 2 weeks to a few months, and constitutional symptoms may precede or accompany the skin eruption [4-10]. In the differential diagnosis, several diseases should be taken into consideration: secondary syphilis (in which the lesions are not scaling, palms/soles are frequently involved, and lymphadenopathy is constantly present); seborrheic dermatitis (usually involving the scalp); nummular eczema (which prefers the shins and the back of the hands, sites only occasionally involved in PR), and pityriasis lichenoides chronica (which has a more chronic and relapsing course without HP).

As for other exanthems, besides the typical presentation of PR, atypical forms have been described [11-15]. Following the early classification of atypical PR [16], Chuh et al. [11] proposed another classification of the PR eruptions that are considered atypical for morphology, size, 
Table 1. Main features of the different PR forms

\begin{tabular}{|c|c|c|c|c|c|c|c|c|}
\hline $\begin{array}{l}\text { Type of } \\
\text { PR }\end{array}$ & Pathogenesis & $\begin{array}{l}\text { Skin } \\
\text { involvement }\end{array}$ & $\begin{array}{l}\mathrm{HP}, \\
\%\end{array}$ & $\begin{array}{l}\text { Mucosal } \\
\text { involve- } \\
\text { ment, } \\
\%\end{array}$ & $\begin{array}{l}\text { Systemic } \\
\text { symptoms, } \\
\%\end{array}$ & Histopathology & $\begin{array}{l}\text { Mean } \\
\text { duration }\end{array}$ & $\begin{array}{l}\text { Therapeutic } \\
\text { options }\end{array}$ \\
\hline Classic & $\begin{array}{l}\text { sporadic } \mathrm{HHV}-6 / 7 \\
\text { systemic } \\
\text { reactivation }\end{array}$ & trunk and limbs & $12-90$ & 16 & $\geq 69$ & $\begin{array}{l}\text { parakeratosis, spongiosis } \\
\text { (epidermis); extravasated } \\
\text { red blood cells, lymphocyte } \\
\text { infiltrate (dermis) }\end{array}$ & 45 days & bed rest \\
\hline Relapsing & $\begin{array}{l}\text { relapsing } \mathrm{HHV}-6 / 7 \\
\text { systemic } \\
\text { reactivation }\end{array}$ & $\begin{array}{l}\text { trunk and limbs } \\
\text { (lesions reduced } \\
\text { in size and } \\
\text { number compared } \\
\text { to the classic } \\
\text { form) }\end{array}$ & 0 & 14 & $\begin{array}{l}100 \text { (less } \\
\text { severe than } \\
\text { the classic } \\
\text { form) }\end{array}$ & $\begin{array}{l}\text { parakeratosis, spongiosis } \\
\text { (epidermis); extravasated } \\
\text { red blood cells, lymphocyte } \\
\text { infiltrate (dermis) }\end{array}$ & 15 days & acyclovir \\
\hline Persistent & $\begin{array}{l}\text { persistence of } \\
\text { HHV-6/7 plasma } \\
\text { viremia }\end{array}$ & trunk and limbs & 75 & 75 & 92 & $\begin{array}{l}\text { parakeratosis, spongiosis } \\
\text { (epidermis); extravasated } \\
\text { red blood cells, lymphocyte } \\
\text { infiltrate (dermis) }\end{array}$ & $>12$ weeks & acyclovir \\
\hline Pediatric & $\begin{array}{l}\text { longer activity of } \\
\text { HHV-6/7 infection } \\
\text { (recent primary } \\
\text { infection) }\end{array}$ & trunk and limbs & 58 & 35 & 48 & $\begin{array}{l}\text { parakeratosis, spongiosis } \\
\text { (epidermis); extravasated } \\
\text { red blood cells, lymphocyte } \\
\text { infiltrate (dermis) }\end{array}$ & 16 days & bed rest \\
\hline Pregnancy & $\begin{array}{l}\mathrm{HHV}-6 / 7 \\
\text { reactivation and } \\
\text { their possible } \\
\text { intrauterine } \\
\text { transmission }\end{array}$ & $\begin{array}{l}\text { trunk and limbs: } \\
\text { widespread lesions } \\
\text { if PR develops } \\
\text { within } 15 \text { weeks of } \\
\text { gestation }\end{array}$ & 50 & 16 & $\begin{array}{l}\geq 69 \text { (more } \\
\text { severe if } \mathrm{PR} \\
\text { develops } \\
\text { within } \\
15 \text { weeks of } \\
\text { gestation) }\end{array}$ & $\begin{array}{l}\text { parakeratosis, spongiosis } \\
\text { (epidermis); extravasated } \\
\text { red blood cells, lymphocyte } \\
\text { infiltrate (dermis) }\end{array}$ & $\begin{array}{l}45 \text { days } \\
(8-12 \text { weeks } \\
\text { if } P R \text { starts } \\
\text { within } \\
15 \text { weeks of } \\
\text { gestation })\end{array}$ & $\begin{array}{l}\text { bed rest and } \\
\text { close follow- } \\
\text { up }\end{array}$ \\
\hline $\begin{array}{l}\text { PR-like } \\
\text { eruption }\end{array}$ & $\begin{array}{l}\text { reaction to a drug/ } \\
\text { vaccine }\end{array}$ & $\begin{array}{l}\text { trunk, limbs, face: } \\
\text { diffuse and } \\
\text { confluent lesions }\end{array}$ & 0 & 50 & 0 & $\begin{array}{l}\text { interface dermatitis and } \\
\text { eosinophils }\end{array}$ & $\begin{array}{l}2 \text { weeks after } \\
\text { discontinu- } \\
\text { ing the drug }\end{array}$ & $\begin{array}{l}\text { drug } \\
\text { withdrawal }\end{array}$ \\
\hline
\end{tabular}

number, distribution, site, severity of symptoms, and course. Overall, the previous classifications of PR are mainly based on its atypical morphological features rather than on the pathogenetic mechanisms that underlie their different presentations. Notably, most of the morphologically atypical forms follow a course amenable to the classic form. We therefore proposed a simplified and comprehensive classification of the PR variants, including the atypical forms, based on the differences in pathogenesis, clinical features, and course of the disease (table 1).

\section{PR Classification}

\section{Classic PR}

The Typical Eruption

The prevalence of classic PR (CPR) has been established at $1.3 \%$ [10], but it is probably underestimated because of the occurrence of atypical forms and the number of patients who are misdiagnosed by nondermatologists. The age of maximum incidence is between 10 and 35 years, without statistically significant variation between sexes $[5,6]$. Although a higher prevalence in cold seasons has been claimed $[7,8]$, controversial opinions remain [9]. In our experience of 613 consecutive PR patients recruited between January 2003 and December 2014 at the Department of Dermatology, University of Genoa, Genoa, Italy, PR occurs uniformly throughout the year.

The typical PR begins in 12-90\% of cases [17] with a solitary patch (HP), which is a medallion-like erythematous patch with slightly elevated finely scaling borders and a paler and slightly depressed center. It usually occurs on the trunk - more rarely on the limbs - and progressively enlarges, reaching $3 \mathrm{~cm}$ or more in diameter. It remains isolated for about 2 weeks, after which the generalized eruption brusquely develops. This secondary eruption is characterized by patches that are similar to the initial one but smaller and symmetrically oriented with their long axes along the cleavage lines (Christmas tree distribution). Oral lesions, occurring in $16 \%$ of Caucasian patients [5], can be categorized into 5 groups: punctuate hemorrhages, erosions or ulcerations (which are the most 
frequent), erythematous macules, erythematous annular lesions, and erythematous plaques. Prodromal symptoms are frequently reported: malaise, nausea, loss of appetite, headache, difficulty in concentration, irritability, gastrointestinal and upper respiratory symptoms (up to 69\%), joint pain, swelling of lymph nodes, sore throat, and mild fever. These symptoms may also be present during the course of the eruption. Itching is severe in $25 \%$ of patients, moderate or mild in 50\%, and absent in 25\% [5]. Classically, PR lasts about 45 days, and the lesions gradually resolve without leaving cutaneous signs [5]. Concerning the pathogenesis, the causal role for systemic active HHV-6/7 infection is based on the detection of HHV-6/7 DNA in the plasma and the expression of mRNA and specific antigens in skin lesions of PR patients. In addition, herpesvirus virions in various stages of morphogenesis have been detected by electron microscopy in skin lesions and in the supernatant of cocultured peripheral blood mononuclear cells of PR patients [1-5].

CPR is easily recognizable: the diagnosis is entirely clinical, and histological examination is not necessary. However, histopathology displays focal parakeratosis, spongiosis, and acanthosis in the epidermis and extravasated red blood cells accompanied by a perivascular infiltrate of lymphocytes, monocytes, and eosinophils in the dermis [5].

Since PR is a self-limiting disease, the best treatment is reassuring the patient and suggesting only bed rest. In a placebo-controlled study, $800 \mathrm{mg}$ of acyclovir 5 times a day hastened the clearance of the lesions [18]. At the moment, however, no treatment can be recommended on the basis of evidence-based medicine.

\section{The Atypical Eruption}

According to Chuh et al. [11], atypical eruption can be classified for the morphology, size, number, distribution, and site of the lesions and for the severity of symptoms and course of the disease.

The lesions may vary morphologically (vesicular, purpuric, hemorrhagic, or urticarial) $[5,11]$. Their size may be particularly large (PR gigantea of Darier) or small (as in papular PR) [10]. As for distribution, the face, axillae, and groin are predominantly affected in inverse PR [10, 19]. Concerning the number and duration of the lesions, 'pityriasis marginata et circinata' of Vidal exhibits large patches often localized to the axillae or inguinal region, with its course spanning for months, suggesting rather an erythema annulare centrifugum [20]. The involvement of the face, scalp, hands, and feet is unusual, and PR of the fingers, scalp, eyelids, and penis is exceptional $[5,10]$.

Pathogenesis, Clinical Features, and Course of the Disease
Itching may be severe with pain and burning sensation (PR irritata) [21], especially if inappropriate topical medications have been applied. Seasonal variations may also occur: PR may be psoriasiform in summer and crusted in winter [22].

\section{Relapsing PR}

CPR is described as relapsing only unusually [10]. Relapsing PR is a variant of the exanthem that recurs usually within 1 year from the initial presentation, possibly due to a temporary drop in cell-mediated immune surveillance on the occasion of psychological/physical strain [13]. Relapsing PR occurs in $2.8 \%$ of the patients according to Bjornberg and Hellgren [10] and 3.7\% in our experience [13]. It consists mostly of a single episode of relapse, though multiple cases have been reported [23, 24]. The relapse rate, however, is probably largely underestimated because it is unlikely that the same physicians who made the initial diagnosis could observe relapses. Another reason to believe that relapses are more frequent than suspected is their diagnostic difficulty. In fact, the HP is usually absent in the recurrences, and both the size and number of the lesions are reduced compared to those of the primary episode [13]. Also, the duration of the relapse (a mean of 15 days) is shorter than that of the primary episode. The associated constitutional symptoms, though less severe than in the primary eruption, are always present [13]. Why relapses usually occur within a restricted time after the primary episode and why they run an atypical course is unknown. Some pathogenetic hypotheses can be made, recalling the behavior of other HHVs, like the Epstein-Barr virus, sharing with HHV-6/7 structural, genomic, and antigenic features and many biological properties. Indeed, during all HHV infections, cell-mediated immunity is crucial for the control of the viral infection and replication. Within 6-12 months after the development of infectious mononucleosis or Epstein-Barr virus reactivation, some patients suffer 'relapses' with constitutional symptoms, a phenomenon that occurs in the intervening time that the immune system takes to regain control of the reactivating virus [25]. Likewise, all PR relapses would take place preferentially within a restricted period of time (6-18 months), a time that is required for the immune system to gain full control of replicating HHV-6/7. In the meantime, the immune system is not completely ineffectual, though it is still recovering from the failure which permitted the reactivation, and this explains why PR relapsing eruptions and systemic symptoms are less severe than in the primary episode. Therefore, it is likely that the relapsing skin eruptions corre- 
spond to relapses of the HHV-6/7 systemic reactivation. Treatment with acyclovir $(800 \mathrm{mg}, 5$ times a day for 10 days) has been reported as effective in interrupting the sequence of relapses [18].

\section{Persistent $P R$}

Persistent PR is an atypical form that lasts for over 12 weeks without interruption, regardless of the presence of constitutional symptoms [14]. In the absence of a diagnostic gold standard test, the persistence of HHV-6/7 plasma viremia (measured by calibrated quantitative real-time PCR) in all the phases of the illness and the persisting PR signs/symptoms are highly suggestive. As in typical PR [5] and in contrast to relapsing PR [13], in most of the patients with persistent $\mathrm{PR}$ the disease begins with the HP (75\%). Systemic symptoms (especially fatigue and impaired concentration) are almost constantly reported, and this is in accordance with the persistent systemic reactivation of HHV-6/7. Oral lesions, resembling Nagayama's spots described in primary HHV-6 infection [26], are also more common than in CPR [27], a further sign of active infection [28]. Moreover, the average level of plasma viremia was higher in persistent PR than in CPR [14]. Over the last 2 years, we treated 5 patients with persistent $P R$ with a high dose of acyclovir $(800 \mathrm{mg}, 5$ times a day for 10 days), obtaining after 4 weeks a nearly complete resolution of the skin lesions, an improvement of the systemic symptoms, and a significant reduction in the serum viral load (unpubl. data), supporting acyclovir use whenever skin lesions and constitutional symptoms are detrimental for the personal and social life of the patient.

\section{Pediatric $P R$}

PR in children may be considered a distinct form due to its peculiar clinical and laboratory features. The disease is uncommon in children younger than 10 years $[15,29]$, and the prevalence of pediatric PR is approximately $8 \%$ in Caucasians $[10,15]$ and higher in dark-skinned children $(26 \%)$ in whom facial and scalp involvement are also more frequent (30 vs. $8 \%$ in Caucasian patients). Also, papular lesions and residual hyperpigmentation prevail $[10,29]$. HP occurs in children as often as in adults (50 vs. $58 \%)[5,10,15]$, but the mean time lapse between HP and generalized eruption is shorter (4 days vs. about 2 weeks). The exanthem duration is shorter as well (16 vs. 45 days in adults) [15]. Oropharyngeal lesions are commoner than in adults (35 vs. $16 \%$ of Caucasian patients [26] and $9 \%$ of dark-skinned patients [29]). Conversely, the prevalence of systemic symptoms is almost identical in adults and children (48\% [15] vs. 69\%) [5]. As in adults, the high-avidity IgG antibody titers and the HHV-6/7 plasma viremia indicate a virus reactivation rather than a primary infection. Moreover, the HHV-6/7 average plasma viremia, both during the acute phase and after recovery, is definitely higher in children than in adults [15]. Considering that the primary HHV-6/7 infection occurs most commonly under the age of 3 years, it is likely that in children the virus load remains higher than in adults. Treatment with antiviral drugs is not recommended, also considering the short duration of the rash.

\section{$P R$ in Pregnancy}

PR has been reported to occur more frequently in pregnancy than in the general population (18 vs. 6\%) [30]. Since pregnancy is a state of altered immune response, a risk of viral reactivations and intrauterine transmission of HHV-6/7 exists. We previously studied 61 women who developed PR during pregnancy, finding that $22(36 \%)$ had unfavorable outcomes, and 8 miscarried (13\%) [31, 32]. Patients with normal pregnancy usually had a CPR, whereas all miscarrying women presented with an atypically aggressive course with skin lesions unusually widespread, exanthem duration of 8-12 weeks, and severe associated constitutional symptoms (fatigue, headache, inability to concentrate, insomnia, and loss of appetite). None of the miscarrying women studied had risk factors, other than PR, for intrauterine fetal death. All of them carried HHV -6 DNA in the plasma, placenta, PR lesions, and fetal tissues, whereas among the 5 patients with perinatal problems only 1 carried HHV-6 DNA in the plasma, PR lesions, and placenta; among the patients with normal pregnancy only 2 carried HHV-6 DNA in the plasma and none in the placenta. HHV-7 DNA was detected in the plasma and PR lesions in 3 of the miscarrying women as well as in patients with normal pregnancy ( 3 cases in the plasma and 2 in PR lesions) but never in fetal tissues. On the whole, the total abortion rate among women with pregnancy PR is the same as that of the general population (13\%), but, noteworthy, when PR develops within the 15th gestational week, the abortion rate is definitely higher (57\%), probably because the risk of intrauterine transmission of HHV-6 (or less commonly HHV-7) is increased. Therefore, in such patients, especially with aggressive PR forms, a closer follow-up should be recommended and HHV-6 DNA investigated in the plasma [31, 32].

\section{PR-Like Eruptions}

PR-like eruption is a drug-induced skin rash with clinical features that strikingly resemble genuine PR and that often do not allow a clear distinction. Distinguishing 
them, nonetheless, is of paramount importance since a typical PR may develop during but independently from a therapy. Recently, criteria have been proposed for distinguishing between the two forms [12,33]. In PR-like eruptions, the erythematopapular lesions are more confluent and itchy than in CPR, involve the limbs more extensively, and in some cases also the face (a site usually spared by CPR). Prodromal systemic symptoms are absent. Laboratory findings of PR-like patients frequently show that blood eosinophilia and HHV-6/7 DNA in the plasma and peripheral blood mononuclear cells is usually negative. Differently from CPR, histopathology reveals necrotic keratinocytes within the epidermis, dermal eosinophil infiltrate, perivascular infiltrate, and signs of junctional vacuolar degeneration. Lastly, patients with PR-like eruptions promptly recovered after discontinuing the drug. Therefore, the clinical, histopathological and virological investigations may definitely help to distinguish typical PR from PR-like eruptions. Many drugs may induce a PRlike eruption, including barbiturates, methopromazine, captopril, clonidine, gold, metronidazole, D-penicillamine, isotretinoin, levamisole, Pyribenzamine, nonsteroidal anti-inflammatory agents, omeprazole, terbinafine, ergotamine tartrate, tyrosine kinase inhibitors, and biological agents (adalimumab) [5]. PR-like rashes have also been reported after vaccinations for diphtheria, smallpox, pneumococcal, hepatitis B virus, BCG, and human papillomavirus $[5,34]$. From a practical viewpoint, to distinguish between PR and PR-like eruptions, and of course whether and when it is necessary to stop the involved drug, is of paramount importance since a typical PR may develop during but independently from a therapy. In such a case, the drug (if indispensable for the health of the patient) may be cautiously continued, whereas in the case of PR-like eruptions it is preferable to withdraw the drug promptly lest more dangerous drug reactions develop $[5,12,33]$.

\section{Discussion}

Although infrequently, like other exanthems, PR shows atypical forms in the morphology of lesions, course, and severity of associated symptoms. An attempt to classify these variants has been done as early as 1924 [16]. More recently, Chuh et al. [11] proposed another classification for these atypical forms considering the morphology, size, number, distribution, site, severity of symptoms, and course of the disease. Overall, such classification takes mainly into account the variations of the rash, the distribu-

Pathogenesis, Clinical Features, and Course of the Disease tion of the lesions and the severity of the cutaneous symptoms. Conversely, our classification system considers mainly the PR clinical course and the pathogenetic mechanisms that underlie the different forms of exanthem, depending in turn on the different modalities of the HHV-6 and/or HHV-7 reactivation. We have essentially divided PR into an adult (classic, relapsing, persistent, and pregnancy PR) and a pediatric form. PR-like eruptions have been considered a distinct and independent form (fig. 1).

In the adult classic form of PR (CPR), the HHV-6/7 systemic reactivation, possibly related to other disorders, drugs, or psychological/physical strain, may determine the typical skin eruption lasting for about 45 days, mucosal lesions, and constitutional symptoms. Notably, PR exanthems with atypical morphology, size, or distribution of the lesions may be regarded as atypical variants of the CPR both for pathogenesis and course [5]. Comparing our new classification with a previous one that collected only the atypical PR forms [11], the overlapping parts are those concerning morphology and distribution of the lesions, aspects that we have included in the CPR (typical and atypical eruptions; fig. 1). More recently, a newer PR classification has also taken into account the prodromal symptoms, the HP features, the number of secondary lesions, their size and orientation, the PR clinical course, and seasonal variations [22]. Comparing this classification with ours, the overlap concerned the clinical course of the exanthem: we consider a classic, relapsing, or persistent course on the basis of the exanthem duration defining the temporal limits of all these forms.

In our classification, the different presentations of $\mathrm{HP}$ and secondary lesions have been included in the CPR as morphological variants, and the seasonal variations have not been taken into account since in our experience PR occurs uniformly throughout the year [5].

The relapsing episodes of PR correspond to relapses in the HHV-6/7 systemic reactivation, occurring within a short period of time and continuing until the immune system has regained control of the viral replication. Nevertheless, in the meantime, the immune system is not completely ineffectual. In fact, the size and number of the lesions are reduced compared to the primary episode, the exanthem duration is shorter, and the associated constitutional symptoms are less severe [13]. Lastly, in persistent PR, the persistence of HHV-6/7 plasma viremia may explain the persistence of the skin eruption for more than 12 weeks as well as the more frequent mucosal involvement and systemic symptoms compared to CPR [14]. The pediatric PR may really be considered a distinct form compared to the CPR. In fact, it differs from it in the patho- 


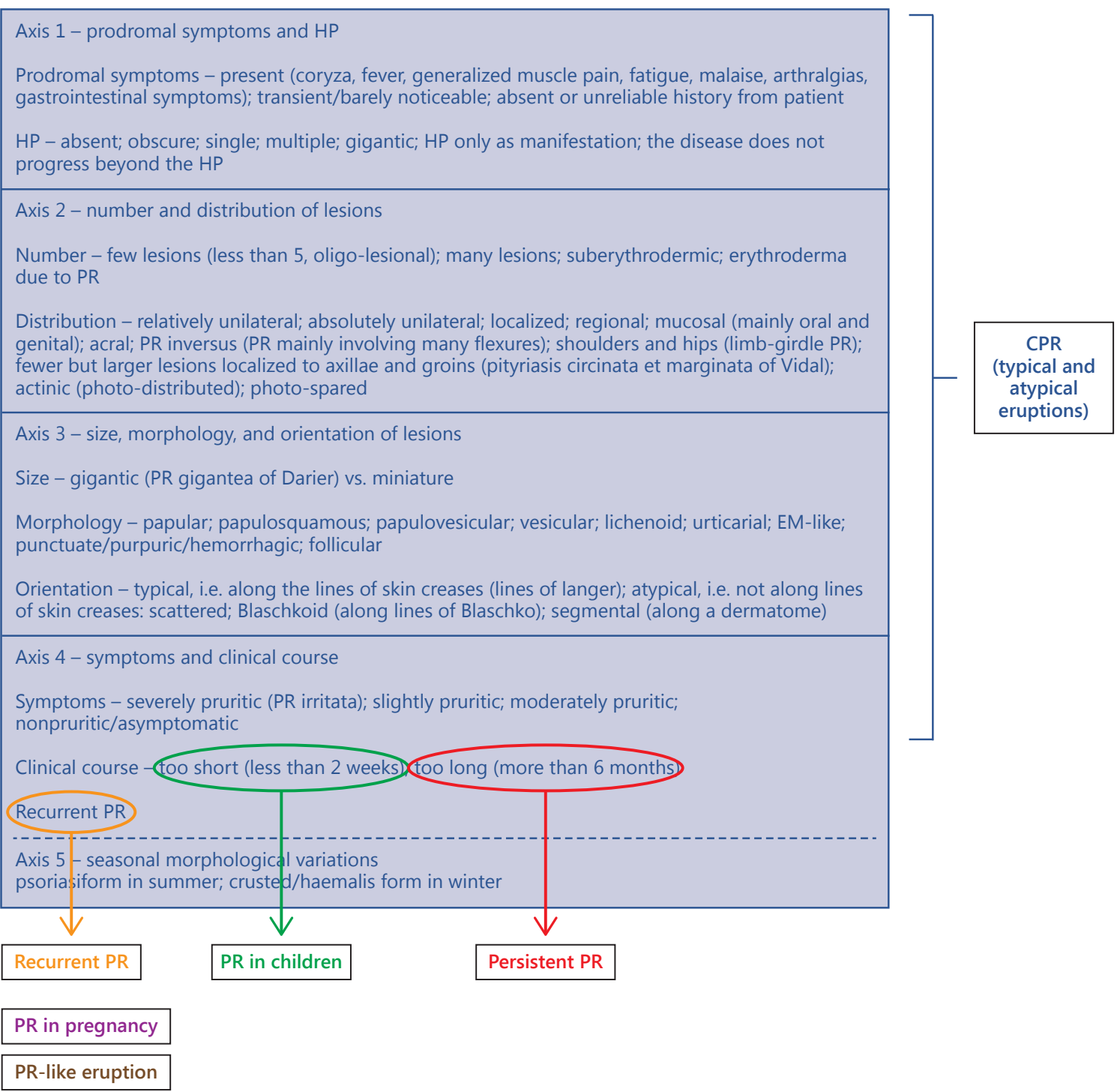

Fig. 1. Comparison between the previous classification of $P R$ (main body) and our classification system (arrows and panels). $\mathrm{CPR}$, in its typical and atypical eruptions, includes all the morphological variants of the previous classification. Considering the course of the disease, we introduced a recurrent and a persistent

genesis and in the clinical and laboratory features. Remarkably, the shorter course of the eruption compared to adults is not explained by an equally shorter persistence of HHV-6/7 plasma viremia. Conversely, in children, the HHV-6/7 average plasma viremia persists even after recovery. Moreover, both during the acute phase and after resolution, plasma viremia are very much higher in children than in adults [15], probably because the primary
PR form. PR in children usually lasts for about 12 days (short course). PR in pregnancy and PR-like eruptions do not fit into any of the previously cited variants of the exanthem. PR in pregnancy may be a CPR, or it may have a particularly aggressive course.

HHV-6/7 infection has occurred more recently and, accordingly, the virus activity is still intensive. PR in pregnancy can be included in CPR, or it can have a more aggressive course with unusually widespread skin lesions, long duration, and severe constitutional symptoms. These atypical forms require a closer follow-up since they may be associated with a prolonged viral reactivation in the plasma, eventually determining a HHV-6 intrauterine 
transmission and even fetal death, especially if PR develops within the 15 th gestational week $[31,32]$. Finally, PRlike eruption is not a true form of $\mathrm{PR}$, with a pathogenesis completely different from the previously described forms. In fact, it is not associated with a systemic HHV -6/7 reactivation but is rather a reaction to a drug that manifests resembling the lesions of the genuine $\mathrm{PR}[5,12,33]$. In conclusion, the classification that we propose, taking into account the pathogenesis, clinical features, and course of the disease, is easy and intuitive. In the clinical practice, it may be especially helpful in identifying the forms of PR that are different from CPR, not only for the rash mor- phology, an aspect that has been considered in the previous classification system, but also for the clinical course, in order to avoid misdiagnosis and establish the best treatment options. Finally, this classification provides indications for managing a potentially harmful form of PR (such as $\mathrm{PR}$ in pregnancy) and PR-like eruptions.

\section{Disclosure Statement}

The authors have no conflicts of interest to disclose. There was no funding for this work.

\section{References}

1 Drago F, Ranieri E, Malaguti F, Losi E, Rebora A: Human herpesvirus 7 in pityriasis rosea. Lancet 1997;349:1367-1368.

- 2 Drago F, Ranieri E, Malaguti F, Battifoglio ML, Losi E, Rebora A: Human herpesvirus 7 in patients with pityriasis rosea. Electron microscopy investigations and polymerase chain reaction in mononuclear cells, plasma and skin. Dermatology 1997;195:374-378.

-3 Watanabe T, Nakamura K, Jacob SE, Aquilino EA, Orestein JM, Black JB, Blauvelt A: Pityriasis rosea is associated with systemic active infection with both human herpesvirus-7 and human herpesvirus-6. J Invest Dermatol 2002;119:793-797.

4 Broccolo F, Drago F, Careddu AM, Foglieni C, Turbino L, Cocuzza CE, Gelmetti C, Lusso P, Rebora A, Malnati MS: Additional evidence that pityriasis rosea is associated with reactivation of human herpesvirus- 6 and -7 . J Invest Dermatol 2005;124:1234-1240.

5 Drago F, Broccolo F, Rebora A: Pityriasis rosea: an update with a critical appraisal of its possible herpesviral etiology. J Am Acad Dermatol 2009;61:303-318.

6 Tay YK, Goh CL: One-year review of pityriasis rosea at the National Skin Centre, Singapore. Ann Acad Med Singapore 1999;28:829-831.

7 Chuang TY, Ilstrup DM, Perry HO, Kurland LT: Pityriasis rosea in Rochester, Minnesota: 1969 to 1978. J Am Acad Dermatol 1982;7: $80-89$.

8 Harman M, Aytekin S, Akdeniz S, Inaloz HS: An epidemiological study of pityriasis rosea in the Eastern Anatolia. Eur J Epidemiol 1998; 14:495-497.

-9 Chuh AA, Dofitas BL, Comisel GG, Reveiz L, Sharma V, Garner SE, et al: Interventions for pityriasis rosea. Cochrane Database Syst Rey 2007;2:CD005068.

$>10$ Bjornberg A, Hellgren L: Pityriasis rosea. A statistical, clinical, and laboratory investigation of 826 patients and matched healthy controls. Acta Derm Venereol Suppl (Stockh) 1962;42(suppl 50):1-68.
11 Chuh A, Zawar V, Lee A: Atypical presentations of pityriasis rosea: case presentations. J Eur Acad Dermatol Venereol 2005;19:120126.

12 Drago F, Ciccarese G, Rebora A, Parodi A: Pityriasis rosea and pityriasis rosea-like eruption: can they be distinguished? J Dermatol 2014; $41: 864-865$

$\checkmark 13$ Drago F, Ciccarese G, Rebora A, Parodi A: Relapsing pityriasis rosea. Dermatology 2014; 229:316-318.

14 Drago F, Broccolo F, Ciccarese G, Rebora A, Parodi A: Persistent pityriasis rosea: an unusual form of pityriasis rosea with persistent active HHV-6 and HHV-7 infection. Dermatology 2015;230:23-26.

15 Drago F, Ciccarese G, Broccolo F, Cozzani E, Parodi A: Pityriasis rosea in children: clinical features and laboratory investigations. Dermatology 2015;231:9-14.

16 Klauder JV: Pityriasis rosea with particular reference to its unusual manifestations. JAMA 1924;82:178-183.

17 Percival GH: Pityriasis rosea. Br J Dermatol 1932:44:241-253

18 Drago F, Vecchio F, Rebora A: Use of highdose acyclovir in pityriasis rosea. J Am Acad Dermatol 2006;54:82-85.

19 Gibney MD, Leonardi CL: Acute papulosquamous eruption of the extremities demonstrating an isomorphic response. Inverse pityriasis rosea (PR). Arch Dermatol 1997;133:654.

20 Zawar V, Godse K: Annular groin eruptions: pityriasis rosea of Vidal. Int J Dermatol 2011; 50:195-197.

21 Eslick GD: Atypical pityriasis rosea or psoriasis guttata? Early examination is the key to a correct diagnosis. Int J Dermatol 2002;41: 788-791.

22 Zawar V, Chuh A: Follicular pityriasis rosea. A case report and a new classification of clinical variants of the disease. J Dermatol Case Rep 2012;6:36-39.

23 Halkier-Sørensen L: Recurrent pityriasis rosea. New episodes every year for five years. A case report. Acta Derm Venereol 1990;70: 179-180.

24 Zawar V, Kumar R: Multiple recurrences of pityriasis rosea of Vidal: a novel presentation. Clin Exp Dermatol 2009;34:e114-e116.

25 Dunmire SK, Hogquist KA, Balfour HH: Infectious mononucleosis. Curr Top Microbiol Immunol 2015;390:211-240.

26 Hall CB, Long CE, Schnabel KC, Caserta MT, McIntyre KM, Costanzo MA, Knott A, Dewhurst S, Insel RA, Epstein LG: Human herpesvirus-6 infection in children. A prospective study of complications and reactivation. N Engl J Med 1994;331:432-438.

27 Vidimos AT, Camisa C: Tongue and cheek: oral lesions in pityriasis rosea. Cutis 1992;50: 276-280.

28 Asano Y, Yoshikawa T, Suga S, Kobayashi I, Nakashima T, Yazaki T, Kajita Y, Ozaki T: Clinical features of infants with primary human herpesvirus 6 infection (exanthem subitum, roseola infantum). Pediatrics 1994;93:104-108.

29 Jacyk WK: Pityriasis rosea in Nigerians. Int $J$ Dermatol 1980;19:397-399.

30 Corson EF, Luscombe HA: Coincidence with pityriasis rosea with pregnancy. AMA Arch Derm Syphilol 1950;62:562-564.

- 31 Drago F, Broccolo F, Zaccaria E, Malnati M, Cocuzza C, Lusso P, Rebora A: Pregnancy outcome in patients with pityriasis rosea. J Am Acad Dermatol 2008;58:S78-S83.

- 32 Drago F, Broccolo F, Javor S, Drago F, Rebora A, Parodi A: Evidence of human herpesvirus-6 and -7 reactivation in miscarrying women with pityriasis rosea. J Am Acad Dermatol 2014;71:198-199.

33 Drago F, Broccolo F, Agnoletti A, Drago F, Rebora A, Parodi A: Pityriasis rosea and pityriasis rosea-like eruptions. J Am Acad Dermatol 2014;70:196.

34 Drago F, Ciccarese G, Javor S, Parodi A: Vaccine-induced pityriasis rosea and pityriasis rosea-like eruptions: a review of the literature. J Eur Acad Dermatol Venereol 2016;30:544545
Pathogenesis, Clinical Features, and Course of the Disease 